\title{
Effectiveness Score of the Board of Directors and Modified Audit Opinion: Empirical Evidence from Malaysian Publicly-Listed Companies
}

\author{
Waddah Kamal Hassan OMER ${ }^{1}$, Khaled Salmen ALJAAIDI ${ }^{2}$, Mohd Atef Md. YUSOF ${ }^{3}$ \\ Received: May 27, 2020 Revised: June 07, 2020 Accepted: July 07, 2020
}

\begin{abstract}
The study investigates the association between the effectiveness of the board of directors and the likelihood that a company receives a modified audit opinion (as a measure of the quality of companies' external financial reporting) in Malaysia. The sample companies were extracted from the population of publicly-available information mainly the annual reports of publicly-listed companies on the Bursa Malaysia. 136 firm-year observations listed on Bursa Malaysia were identified to examine the relationship between the effectiveness of the board of directors and a modified audit opinion. Data used in this study are collected from two separate sources - annual reports and Datastream. Any missing financial figure from Datastream was acquired from the annual reports. To test the study's hypotheses, we use the pooled cross-sectional logistic regression analysis for 136 firm-year observations listed on Bursa Malaysia over the period 2009-2011. The evidence we have uncovered is consistent with the hypothesis that companies with large score of the board of directors' effectiveness are less possible to receive a modified audit opinion. Therefore, the result confirms that the combined effect of the board of directors' characteristics has a significant negative association with the likelihood of the companies receiving a modified audit opinion.
\end{abstract}

Keywords: Modified Audit Opinion, Financial Reporting Quality, Board of Directors, Effectiveness Score, Malaysia

JEL Classification Code: G34, M42

\section{Introduction}

In real life, a series of giant companies around the world collapsed, such as Enron and Worldcom in the US, Parmalat, Ahold, Gescartera and BBVA in Europe (to name a few). It has been shown that most corporate failures were

${ }^{1}$ First Author and Corresponding Author. [1] Assistant Professor, Department of Accounting, College of Business Administration, Northern Border University, Saudi Arabia; [2] Accounting Department, Faculty of Administrative Sciences, University of Aden, Yemen. [Postal Address: 6907 Khalid Bin Al-Waleed Street, Apartment No.4, Al-Khalij District, Turaif Governorate, 75311-4578, Kingdom of Saudi Arabia] Email: waddahkam@yahoo.com

${ }^{2}$ Assistant Professor, Accounting Department, College of Business Administration, Prince Sattam bin Abdulaziz University, Saudi Arabia.Email: k.aljaaidi@psau.edu.sa

${ }^{3}$ Assistant Professor, School of Accounting, College of Business, Universiti Utara Malaysia, Malaysia. Email: atef@uum.edu.my

(c) Copyright: The Author(s)

This is an Open Access article distributed under the terms of the Creative Commons Attribution Non-Commercial License (http://Creativecommons.org/licenses/by-nc/4.0/) which permits unrestricted noncommercial use, distribution, and reproduction in any medium, provided the original work is properly cited. caused by the lack of internal monitoring of management in the financial reporting process arising from poor corporate governance of companies (Agrawal \& Chadha, 2005; Deng \& Wang, 2006; Charitou, Louca, \& Vafeas, 2007; Che Haat, Abdul Rahman, \& Mahenthiran, 2008; Lin \& Hwang, 2010; Darus \& Mohamad, 2011). Malaysia is no exception, pervasive cases of fraudulent financial reporting and failures (e.g., Megan Media Hodlings Berhad, NasionCom Hodlings Berhad, United U-LI Corporation Berhad and Transmile Group Berhad) emerged in the marketplace. Under such circumstance, there are several well-known cases reported in Malaysia involving modified audit opinion as a result of lower financial reporting quality. Therefore, these cases of corporate financial reporting failures have raised question marks on the financial reporting quality, and the effectiveness of the board of directors as the main internal corporate monitoring mechanisms of management in the Malaysian setting (Johari, Mohd Saleh, Jaffar, \& Hassan, 2008; Darus \& Mohamad, 2011). Therefore, this study seeks to answer the following question: Does the effectiveness score of the board of directors' characteristics in aggregated test (i.e., independence, size, meetings and financial 
expertise) decrease the probability of Malaysian publiclylisted companies receiving a modified audit opinion?

It is argued that one vital internal monitoring mechanism that can be used to enhance the financial reporting quality is the effectiveness of the board of directors. Previous studies that have examined the association between board of directors' characteristics and the likelihood of a company receiving a modified audit opinion (Sanchez-Ballesta \& Garcia-Meca, 2005; Firth, Fung, \& Rui, 2007; Rusmin, Tower, Brown, \& der Zahn, 2009; Farinha \& Viana, 2009), have so far uncovered somewhat mixed results. It has been shown that the reasons for such conflicting results could be attributed to the omission of some important characteristics and the examination of each individual board characteristic in isolation from each other (Vafeas \& Theodorou, 1998; Ward, Brown, \& Rodriguez, 2009).

Specifically, this study tries to add an extra empirical evidence on the combined effect of board of directors' characteristics (independence, size, meetings, and financial expertise) with the audit opinion modifications. To resolve agency problems, previous studies ignored the idea that the effectiveness of a particular mechanism may depend on the effectiveness of others (Ward et al., 2009). Arguably, it may be misleading to show the impact of individual characteristics on a modified audit opinion, on the basis of the argumentations of prior studies in other disciplines (e.g, Rediker \& Seth, 1995; Agrawal \& Knoeber, 1996; Davis \& Useem, 2002; Agrawal \& Chadha 2005; Cai, Liu, \& Qian, 2009; Ward et al., 2009). It is also more feasible to investigate the board of directors' characteristics as a whole and not individually, as they are believed to complement each other in determining the effectiveness of the board of directors in its monitoring role. Therefore, the optimal combination of characteristics of the board of directors seems to lead to more effective monitoring activities, and influence the financial reporting oversight that, in turn, reduces the probability of a company receiving a modified audit opinion.

To the best of the researchers' knowledge there are a few studies that have examined the relationship between the board of directors' characteristics and the possibility of a company receiving a modified audit opinion. Thereon, prior literature focuses on individual characteristics of board of directors' practices as established by prior literature with a view to decreasing the probability of receiving a modified audit opinion. This leaves the question whether is it sufficient to focus on disparate characteristics of board of directors' aspects. Which aspects of the board of directors' characteristics are useful to avoid receiving a modified audit opinion? How can a mix of aspects of board of directors' characteristics be achieved to ensure that avoiding receiving a modified audit opinion is addressed much more comprehensively? These are the questions, which triggered the present study.
Moreover, notwithstanding that most of the Malaysian publicly-listed companies that have received modified audit opinions, are linked to lower financial reporting quality in our study period, no study so far has investigated the effect of the characteristics of the board of directors on a modified audit opinion in the Malaysian context. This motivates the researchers to investigate the association between the effectiveness score of the board of directors' characteristics and the modified audit opinion as a particular dimension for the quality of financial reporting. The data used in this study are drawn from the annual reports of a sample of non-financial Malaysian publicly-listed companies, which received modified audit opinion between 2009 and 2011, as a test sample with companies that received an unmodified audit opinion over the same period such as matched-pair sample. The results of this study should be of interest in providing a basis for regulatory actions, namely, those aiming to influence the structure of the board of directors.

Our study contributes to the existing literature that examines the corporate governance variables associated with audit opinions (e.g., Sanchez-Ballesta \& Garcia-Meca, 2005; Firth et al., 2007; Rusmin et al., 2009; Farinha \& Viana, 2009), by empirically linking the board of directors' characteristics with the probability that a company receives a modified audit opinion in an aggregated test. In this respect, this study seeks to extend the work of Farinha and Viana (2009) by empirically investigating how the effectiveness of the board of directors' influence on the likelihood of receiving a modified audit opinion, which is our measure of financial reporting quality, in Asian country economies especially in Malaysia.

The remainder of the paper is arranged as follows. The following section reviews the literature and develops the hypothesis. It is followed by a description of the methodology and presentation of the results. The final section concludes the paper with a discussion of the findings and the limitations of the study with a number of suggestions for future studies.

\section{Literature Review}

The financial reporting quality can be judged through the type of audit opinion issued by the external auditor (Cohen, Krishnamoorthy, \& Wright, 2004). The auditor report is the final product of the audit examination that auditors use to communicate to users of the company's financial statements (Porter, Simon, \& Hatherly, 2003, p. 366). Therefore, it has a major role to play in informing financial statement users of the impending problems with the company's financial reporting or controls of internal processes (Hope \& Langli, 2010). The auditor's report may be classified into two types: unmodified and modified audit opinions (including qualified, disclaimed, and adverse opinions), as mentioned in the International Standard on Auditing (ISA, 700). 
Waddah Kamal Hassan OMER, Khaled Salmen ALJAAIDI, Mohd Atef Md. YUSOF /

Similar to other countries, in Malaysia, the auditors issue unmodified audit opinion if they obtained sufficientlyappropriate audit evidence supporting the disclosures and numbers within the financial statements (referred to the quality of the financial reporting). This exists when the financial statements are prepared in all material aspects in compliance with GAAP and conforms to the applicable financial reporting framework. Otherwise, a modified audit report is issued (Farrugia \& Baldacchino, 2005).

The existence of a modified opinion is an indicator of lower financial reporting quality that may impose on the shareholders the need to institute some forms of controls (Firth et al., 2007; Pucheta-Martinez \& de Fuentes, 2007; Farinha \& Viana, 2009). In this respect, various contractual mechanisms, including the board of directors is one of the vital internal corporate governance mechanisms that mitigate agency problems inherent in managing any company and protect the shareholders interest, through its role in monitoring the management to enhance integrity of the financial reporting process, and enhancing the reliability of financial information (Watts \& Zimmerman, 1986), ultimately increasing financial reporting quality, therefore, reducing the propensity to obtain a modified audit opinion (Sanchez-Ballesta \& Garcia-Meca, 2005; Firth et al., 2007; Farinha \& Viana, 2009).

In the context of corporate governance, the characteristics of the board influence its effectiveness in monitoring the management and, thus, enhance the quality of financial reporting (e.g., Cohen et al., 2008; Farinha \& Viana, 2009; Goh, 2009; Garc1'a Lara, Garc1'a Osma, \& Peñalva, 2009; Lorca, Sa'nchez-Ballesta, \& Garci'a-Meca, 2011). The effectiveness of the board of directors indicate its ability to carry out its specific oversight responsibilities to guarantee the quality of financial reporting practices and assess the quality of corporate governance within the company. Nevertheless, diverging board of directors' characteristics may determine the effectiveness of its monitoring role in the financial reporting process, which consequently impact on the quality and the reliability of financial reporting. Prior studies, which examine the effect of the characteristics of the board of directors in isolation from each other with the modified audit opinion, have uncovered that some of those characteristics have an important impact on the propensity to obtain or avoid a modified audit opinion, as a measure of the quality of companies external financial reporting.

However, previous studies that examine the relationship between the individual characteristics of board of directors and modified audit opinion are small in number and they provide unclear results. This is because these studies are narrow in their focus and they omit several variables that could influence the effectiveness of the board of directors. For example, some studies examined the characteristics of the board of directors' independence (e.g., Iskandar et al., 2011), while ignoring the importance of the other characteristics such as board of directors' size, meetings and financial expertise. Furthermore, other studies examined the characteristics of the independent non-executive directors, board of directors' size, and board of directors' meetings (e.g., Firth et al., 2007; Farinha \& Viana, 2009); they disregard the importance of other characteristics such as board of directors' financial expertise. Thus, examining the characteristics of board of directors in isolation from each other may be the reason that explains why previous studies reach unclear results (Vafeas \& Theodorou, 1998; Ward et al., 2009). The literature has so far not investigated the combined effect of those characteristics on a modified audit opinion, through aggregate test. Therefore, it is expected that these characteristics act in a complementary function related to issues of modified audit opinion. This study develops it hypothesis based on the arguments above to contribute to the debate on the proposed relationship. Thus, the following hypothesis is proposed:

$\boldsymbol{H}$ : There is a negative association between board of directors' effectiveness score and the probability that a company receives a modified audit opinion, all else constant.

\section{Data and Methodology}

The sample companies were extracted from the population of publicly-available information; mainly annual reports of publicly-listed companies on the Bursa Malaysia that received modified audit opinion in the 2009-2011 period as a test sample. Each firm year of the test sample is matched with company that received an unmodified audit opinion as a control test (matched-pair sample) in the event year. Some 136 firm-year observations listed on Bursa Malaysia were identified to examine the relationship between the effectiveness of the board of directors and a modified audit opinion. Data used in this study are collected from two separate sources - annual reports and Datastream. Any missing financial figure from Datastream was acquired from the annual reports. The annual reports were retrieved from the Bursa Malaysia website at www.bursamalaysia. com.my. Based on a qualitative approach, this study utilized descriptive statistics and correlation tools. We examine the relationship between independent variables and modified audit opinion in an aggregate test where we test our hypothesis by using the following cross-sectional logistic regression model:

$$
\begin{aligned}
\mathrm{MAO}= & \beta 0+\beta 1 \text { BDEScoreM }+\beta 2 \text { AUDSIZE }+\beta 3 \\
& \operatorname{logAUDLAG}+\beta 4 \text { LOSS }+\beta 5 \text { NCFGOAR }+\beta 6 \\
& \text { LogEAF }+\mathrm{e}
\end{aligned}
$$


where: Modified audit opinion (MAO) will take the value of 1 if the opinion is a modified one, and otherwise 0 .

The independent variables are defined as follows:

BDEScoreM (Board of directors effectiveness score) 6 = A dummy variable will take the value of " 1 " if the company's board of directors' effectiveness scores equals or more than the scores of sample median, and " 0 " otherwise (DeFond, Hann, \& Hu, 2005); AUDSIZE = size audit firm (Big 4 vs. Non-Big 4); logAUDLAG = the natural logarithm of the audit report lag; LOSS $=$ a negative net income of a company; NCFGOAR = percentage of net cash flow generated from operating activities; $\operatorname{LogEAF}=\log$ of external audit Fees.

To minimize the effect of the expunged variables and to increase the predictive ability of the model we include several control variables (Farinha \& Viana, 2009; Firth, et al., 2007). Variables such as audit firm size, audit report lag, losses and operating cash flow; prior studies have uncovered an association with modified audit opinion (Pucheta-Martínez \& de Fuentes, 2007; Firth, et al., 2007; Goh, 2009; Farinha \& Viana, 2009; Rahmat, Iskandar, \& Saleh, 2009; Sultanoglu, Mugan, Sekerdag, \& Oran, 2018; Alkilani, Hussin, \& Salim, 2019a).

\section{Empirical Results and Discussion}

\subsection{Descriptive Statistics and Univariate Analyses}

Table 1 provides descriptive statistics and univariate test results for variables measured as continuous metrics. In this table, summary statistics for the total groups of sample, modified audit opinion (test sample) and unmodified audit opinion (the matched-pair sample) as a control test sample are tabled in separate columns.

Table 2 presents the descriptive statistics and univariate test results for (dummy) variables by audit opinion. Like the previous t-test, the analysis in this table is related to the relationship between modified audit opinion and unmodified audit opinion in order to be consistent with the multivariate model. The results of the Mann-Whitney U-test for the distribution differences between modified audit opinion and unmodified audit opinion reveals those audit firm size $A U D S I Z E$, and board of directors' effectiveness score $B D E S c o r e M$, for the study Model, are statistically insignificant. In this case, we can argue that these variables are statistically independent from the type of opinion being granted by the auditor (at the $10 \%$ level of significance). This result indicates there is no evidence of significant

Table 1: Descriptive statistics

\begin{tabular}{|c|c|c|c|c|c|c|c|c|c|c|c|c|c|}
\hline \multicolumn{6}{|c|}{ Total Groups of Sample } & \multicolumn{3}{|c|}{$\begin{array}{c}\text { Test sample (the } \\
\text { recipients of modified. } \\
\text { A.0) }\end{array}$} & \multicolumn{3}{|c|}{$\begin{array}{l}\text { Control test sample } \\
\text { (the recipients of } \\
\text { Unmodified. A.O) }\end{array}$} & \multicolumn{2}{|c|}{$\begin{array}{l}\text { Modified. A.O } \\
\text { Vs Unmodified. } \\
\text { A.O t-test }\end{array}$} \\
\hline Variables & Mean & Median & Min & Max. & $\begin{array}{c}\text { Std. } \\
\text { Deviation }\end{array}$ & Mean & Median & $\begin{array}{c}\text { Std. } \\
\text { Deviation }\end{array}$ & Mean & Median & $\begin{array}{c}\text { Std. } \\
\text { Deviation }\end{array}$ & t-stat & \begin{tabular}{|l}
$P$ value \\
Sig. \\
(2-tailed)
\end{tabular} \\
\hline $\log A \cup D L A G$ & 4.655 & 4.754 & 3.912 & 4.942 & .211 & 4.762 & 4.779 & .069 & 4.547 & 4.635 & .248 & 6.805 & 000 \\
\hline NCFGOAR & .578 & .036 & -1.73 & 36.696 & 4.404 & -.030 & .003 & .234 & 1.185 & .084 & 6.187 & -1.594 & .113 \\
\hline LogEAF & 4.989 & 4. 963 & 3.90 & 6.42 & .401 & 4.975 & 4.977 & .391 & 5.002 & 4.937 & .413 & -.399 & .690 \\
\hline
\end{tabular}

Table 2: Descriptive statistics (percentage) and univariate test results

\begin{tabular}{|c|c|c|c|c|}
\hline \multirow{2}{*}{\multicolumn{2}{|c|}{ Variables }} & \multicolumn{2}{|c|}{ Type of audit opinion } & \multirow{2}{*}{ Mann-Whitney U-test } \\
\hline & & Modified & Unmodified & \\
\hline \multirow{2}{*}{ AUDSIZE } & BIG 4 & $21(43 \%)$ & $28(57 \%)$ & \multirow{2}{*}{.209} \\
\hline & Non-BIG 4 & $45(54 \%)$ & $38(46 \%)$ & \\
\hline \multirow{2}{*}{ LOSS } & Loss & $48(76 \%)$ & $18(24 \%)$ & \multirow{2}{*}{.000} \\
\hline & UnLoss & $9(16 \%)$ & $57(84 \%)$ & \\
\hline \multirow{2}{*}{ BDEScoreM } & BDESCORE & $6(50 \%)$ & $60(50 \%)$ & \multirow{2}{*}{1} \\
\hline & UnBDESCORE & $6(50 \%)$ & $60(50 \%)$ & \\
\hline
\end{tabular}


Waddah Kamal Hassan OMER, Khaled Salmen ALJAAIDI, Mohd Atef Md. YUSOF /

differences between the two groups of audit opinion samples for audit firm size AUDSIZE, for study Model (modified audit opinion group: .43; unmodified audit opinion group: .57 ) and board of directors' effectiveness score BDEScoreM, (modified audit opinion group: .50; unmodified audit opinion group: .50).

Based on our observation, majority of our sample was audited by the Non-BIG 4 audit firms $(63 \%)$, which reported that the modified audit opinion group audited by (BIG 4: .32; Non-BIG 4: .68) and unmodified audit opinion group audited by (BIG 4: .42; Non-BIG 4: .58). This is inconsistent with previous studies such as Farinha and Viana (2009) who reported that the Big 4 auditors are responsible, directly or through subsidiaries, for about $70 \%$ of the audit reports in Portugal.

Meanwhile, in study Model; the differences in loss in previous years LOSS samples was found to be highly significant at $\mathrm{p}<.000$. This result is consistent with prior audit reporting research (Johl, Jubb, \& Houghton, 2007; Firth et al., 2007; Pucheta-Martínez \& de Fuentes, 2007; Farinha \& Viana, 2009), the modified audit opinion group was more likely to has a loss and more likely to have received a modified audit opinion than the unmodified audit opinion group.

Regarding to the existence of multicollinearity problems among the independent variables, several examinations have been identified to check for the possible existence of multicollinearity. These include the correlation matrix, variance inflation factor (VIF), and tolerance (1/VIF). In terms of the correlation matrix, in this study, the correlation matrices confirm that no multicollinearity exists among the variables in the study model, modified audit opinion model as none of the variables correlates equal or above 0.80 , which is the first indication of the absence of a substantial collinearity problem between the independent variables (Hair, Anderson, Tatham, \& Black 1995; Greene, 1999; Cooper \& Schindler, 2003). Among independent variables, the highest correlation is equal to -0.501, found for BSIZE and BINEDR in modified audit opinion; all the variables have a correlation below the critical limit of 0.80 , as shown in Table 3 . This provides indications that multicollinearity is not a problem in the study model estimations.

With regard to the (VIF) and the tolerance (1/VIF), in general, the existence of multicollinearity problems is detected if the variance inflation factors (VIF) are more than 10 and tolerance value is less than 0.10 (Hair, Black, Babin, Anderson, \& Tatham, 2006; Pallant, 2007). Based on the analyses, variance inflation factors (VIF) and the tolerance $(1 / \mathrm{VIF})$ for the study model report in this study do not exceed (10) and (0.10), respectively, as shown in Table 4. This indicates that multicollinearity is not a problem to model explanation in this study.

\subsection{Multivariate Logistic Regression Results}

The results of multivariate logistic regression for testing the hypothesis are illustrated in Table 5. In view of model, with respect to the board of directors' effectiveness score, across the modified audit opinion model, we observe a negative significant relationship at the $5 \%$ level between the board of directors' effectiveness score and the probability of a company receives a modified audit opinion. This suggests

Table 3: Correlation matrix

\begin{tabular}{|c|c|c|c|c|c|c|c|c|c|}
\hline Variables & $\begin{array}{l}\frac{\tilde{u}}{\mathrm{u}} \\
\frac{\mathrm{u}}{\mathrm{m}}\end{array}$ & $\begin{array}{l}\frac{W}{N} \\
\frac{\boldsymbol{m}}{}\end{array}$ & 点 & 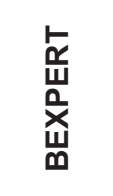 & $\begin{array}{l}\text { U⿺ } \\
\frac{\mathrm{N}}{\mathrm{N}} \\
\frac{\mathrm{O}}{2}\end{array}$ & 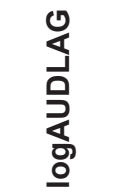 & क् & 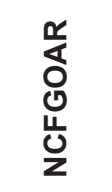 & 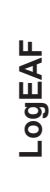 \\
\hline BINEDR & 1 & & & & & & & & \\
\hline BSIZE & -0.501 & 1 & & & & & & & \\
\hline BMEET & 0.115 & -0.102 & 1 & & & & & & \\
\hline BEXPERT & 0.148 & -0.175 & 0.069 & 1 & & & & & \\
\hline AUDSIZE & -0.118 & 0.220 & -0.095 & 0.001 & 1 & & & & \\
\hline $\log A U D L A G$ & 0.228 & -0.242 & 0.222 & -0.039 & -0.294 & 1 & & & \\
\hline LOSS & 0.179 & -0.207 & 0.323 & 0.055 & -0.122 & 0.371 & 1 & & \\
\hline NCFGOAR & -0.1163 & 0.342 & -0.051 & -0.006 & 0.169 & -0.382 & -0.026 & 1 & \\
\hline LogEAF & -0.173 & 0.286 & 0.062 & 0.001 & 0.251 & -0.093 & 0.019 & 0.439 & 1 \\
\hline
\end{tabular}


Table 4: Multicollinearity statistics

\begin{tabular}{|l|c|c|}
\hline \multirow{2}{*}{ Variable } & \multicolumn{2}{|c|}{ Collinearity statistics } \\
\cline { 2 - 3 } & $\begin{array}{c}\text { Variance Inflation } \\
\text { Factor (VIF) }\end{array}$ & $\begin{array}{c}\text { Tolerance Value } \\
\text { (1/VIF) }\end{array}$ \\
\hline BSIZE & 1.60 & 0.625037 \\
\hline NCFGOAR & 1.57 & 0.635029 \\
\hline logAUDLAG & 1.54 & 0.648776 \\
\hline BINEDR & 1.40 & 0.713934 \\
\hline LogEAF & 1.38 & 0.726451 \\
\hline LOSS & 1.31 & 0.765711 \\
\hline AUDSIZE & 1.18 & 0.847022 \\
\hline BMEET & 1.15 & 0.870852 \\
\hline BEXPERT & 1.05 & 0.948456 \\
\hline Mean VIF & 1.35 & \\
\hline
\end{tabular}

that an increase in board of directors' effectiveness score will improve the board of directors' ability to monitor the management. That would lead to enhance internal control in the company, which enhances financial report quality and consequently, reduces the probability of receiving a modified audit opinion. Thus, this leads to mitigating the agency problems and decreasing its cost, and in turn, safeguarding all shareholders' interests. This is consistent with the theoretical model and the stated hypothesis. Hence, it can be inferred that the hypothesis of this study is accepted. This result is in line with the view that the measurement of the combined impact indicates a stronger effect as compared to measurement of individual impacts (O'Sullivan, Percy, $\&$ Stewart, 2008). This is because of the effectiveness of the board of directors achieved through various channels and specific characteristic effectiveness hinges on the effectiveness of other characteristics.

With regard to control variables, as expected in the study model, all the control variables are significant in the predicted directions except for audit firm size AUDSIZE and external audit fees LogEAF, which are insignificant with the modified audit opinion across study model. The results uncovered in this study provides some preliminary evidence that a modified audit opinion is associated with the financial expertise of the board of directors, the size of the board of directors and the combined effect of the board of directors' characteristics. In doing so, this study contributes to the literature on modified audit opinion and narrows the gap in the accountancy literature.

\section{Conclusion}

According to the combined effect of the board of directors' characteristics, our results in the model of this study, indicate that certain board of directors' characteristics complement each other to become more effectiveness in monitoring of the management. A combination (i.e., score) of board characteristics can increase the negative association with a modified audit opinion. This is because that the characteristics act in a complementary function in monitoring role. That leads to increase the effectiveness of the board of directors in its monitoring role to enhance the quality of the financial reporting, which, consequently, decreases the probability of receiving a modified audit opinion. This result supports the agency theory, with the idea that the impact of the board of directors as an internal governance mechanism on a modified audit opinion is complementary and not substitutive.

Table 5: Results of the multivariate logistic regression

\begin{tabular}{|c|c|c|}
\hline \multicolumn{3}{|c|}{ Modified audit opinion Model } \\
\hline Variables & Expected Sign & $\begin{array}{c}\text { Coefficient } \\
\text { (p-value) }\end{array}$ \\
\hline Constant & $?$ & $\begin{array}{c}-77.303 \\
(0.001)\end{array}$ \\
\hline AUDSIZE & + & $\begin{array}{c}.229 \\
(0.721) \\
\end{array}$ \\
\hline $\log A U D L A G$ & + & $\begin{array}{c}16.512 \\
(0.001)^{* \star *}\end{array}$ \\
\hline LOSS & + & $\begin{array}{c}2.451 \\
(0.000)^{* * *}\end{array}$ \\
\hline NCFGOAR & - & $\begin{array}{c}-11.289 \\
(0.001)^{* * *}\end{array}$ \\
\hline LogEAF & + & $\begin{array}{c}.304 \\
(0.708) \\
\end{array}$ \\
\hline BDEScoreM & & $\begin{array}{c}-3.414 \\
(0.027)^{\star \star}\end{array}$ \\
\hline Log Likelihood & & -42.001 \\
\hline $\begin{array}{l}\text { Hosmer- } \\
\text { Lemeshow }\end{array}$ & & 0.685 \\
\hline $\operatorname{LR}_{\operatorname{chi}}^{2}(9 ; 6)$ & & 98.99 \\
\hline Prob > Chi² & & 0.000 \\
\hline Coxsnell $R^{2}$ & & 0.528 \\
\hline Nagelkerke $R^{2}$ & & 0.704 \\
\hline Pseudo $R^{2}$ & & 0.5410 \\
\hline $\begin{array}{l}\text { Correctly } \\
\text { Classified (\%) }\end{array}$ & & 81.8 \\
\hline $\begin{array}{l}\text { No. of } \\
\text { Observations }\end{array}$ & & 132 \\
\hline \multicolumn{3}{|c|}{$\begin{array}{l}\text { All } p \text {-values are one-tailed significance. } \\
{ }^{* * *} \text { are significant at } p<0.01,{ }^{* *} \text { are significant at } p<0.05 \text { and }{ }^{*} \text { at } \\
0.10 \text {. }\end{array}$} \\
\hline
\end{tabular}


Waddah Kamal Hassan OMER, Khaled Salmen ALJAAIDI, Mohd Atef Md. YUSOF /

Journal of Asian Finance, Economics and Business Vol 7 No 8 (2020) 289-296

It can be inferred that the increase in effectiveness of board of directors relates to increase in the characteristics that enhance the board's monitoring, which, lead to enhancing the financial reporting quality, thereby decreasing the probability of receiving a modified audit opinion. Hence, this study concludes that the board of directors with more independent non-executive directors, more members, more regular meetings, and appointed directors with a financial expertise enhances its monitoring role on financial reporting processes in Malaysia. Likewise, together with others, this study is subject to a number of limitations. Foremost, we focused on a few aspects of the board of directors' characteristics. Clearly, there may be other characteristics of the board of directors that could affect the results, such as the legal experts, ethnicity (indigenous vs. non-indigenous) and business knowledge (industry expertise), which may have an influence on a modified audit opinion. In addition, there might be other variables that impact on the probability of receives a modified audit opinion, but they are not included in this study, such as the characteristics of the audit committee and the ownership structure. Future studies possibly will address the issues.

\section{References}

Agrawal, A., \& Chadha, S. (2005). Corporate governance and accounting scandals. Journal of Law and Economics, 48(2), 371-406. https://doi.org/10.1086/430808

Agrawal, A., \& Knoeber, C.R. (1996). Firm performance and mechanisms to control agency problems between managers and shareholders. Journal of Financial and Quantitative Analysis, 31(3), 377-397. https://doi.org/10.2307/2331397

Alkilani, S. Z., Hussin, W. N. W., \& Salim, B. (2019a). The Influence of Audit Committee Characteristics on Modified Audit Opinion in Jordan". Journal of Finance and Accounting. 7(3), 95-106. DOI: $10.11548 /$ jfja20190703.14

Cai, J., Liu, Y., \& Qian, Y., (2009). Information asymmetry and corporate governance. Working Paper, Temple University.

Charitou, A., Louca, C., \& Vafeas, N. (2007). Boards, ownership structure and involuntary delisting from the New York Stock Exchange. Journal of Accounting and Public Policy, 26(2), 249-262. https://doi.org/10.1016/j.jaccpubpol.2007.02.006

Che Haat, M. H., Abdul Rahman, R., \& Mahenthiran, S. (2008). Corporate governance, transparency and performance of Malaysian companies. Managerial Auditing Journal, 23(8), 744-778. https://doi.org/10.1108/02686900810899518

Cohen, J. R., Krishnamoorthy, G., \& Wright, A. M. (2008). Form versus Substance: The Implications for Auditing Practice and Research of Alternative Perspectives on Corporate Governance. Auditing: A Journal of Practice \& Theory, 27(2), 181-198. https://doi.org/10.2308/aud.2008.27.2.181
Davis, G. F., \& Useem, M. (2002). Top management, company directors, and corporate control. Handbook of Strategy and Management, 233-259.

Darus, F., \& Mohamad, A. (2011). Corporate Governance and Corporate Failure in the Context of Agency Theory. The Journal of American Academy of Business, Cambridge, 17(1), 125-132.

DeFond, M. L., Hann, R. N., \& Hu, X. (2005). Does the market value financial expertise on audit committees of boards of directors? Journal of Accounting Research, 43(2), 153-193. https://doi.org/10.1111/j.1475-679x.2005.00166.x

Deng, X., \& Wang, Z. (2006). Ownership structure and financial distress: Evidence from public listed company in China. International Journal of Management, 23(3), 486-503.

Farinha, J., \& Viana, L. F. (2009). Board Structure and Modified Audit Opinions: Evidence from the Portuguese Stock Exchange. International Journal of Auditing, 13(3), 237-258. https://doi. org/10.1111/j.1099-1123.2009.00394.x

Farrugia, K. J., \& Baldacchino, P. J. (2005). Qualified audit opinions in Malta. Managerial Auditing Journal, 20(8), 823-843. DOI: 10.1108/02686900510619674

Firth, M., Fung, P. M. Y., \& Rui, O. M. (2007). Ownership, two-tier board structure, and the informativeness of earnings: Evidence from China. Journal of Accounting and Public Policy, 26(4), 463-496. DOI: 10.1016/j.jaccpubpol.2007.05.004

Garcia Lara, J. M., Garcia Osma B., \& Penalva, F. (2009). Accounting Conservatism and Corporate Governance. Review of Accounting Studies, 14(1), 161-201.doi.org/10.1007/s11142007-9060-1

Goh, B. W. (2009). Audit Committees, Boards of Directors, and Remediation of Material Weaknesses in Internal Control. Contemporary Accounting Research 26(2), 549-579. DOI: 10.1506/car.26.2.9

Hair, J. F., Black, W. C., Babin, B. J., Anderson, R. E., \& Tatham, R. J. (2006). Multivariate data analysis (6th Ed.). Englewood Cliffs, NJ : Pearson International Edition.

Hair, J. F., Anderson, R. E., Tatham, R. L., \& Black, W. C. (1995). Multivariate data analysis (4th ed.). Englewood Cliffs, NJ: Prentice-Hall, Inc.

Hope, O.-K.., \& Langli, J. C. (2010). Auditor Independence in a Private Firm and Low Litigation Risk Setting. The Accounting Review, 85(2), 573-605. DOI: 10.2308/accr.2010.85.2.573

Johari, N. H., Mohd Saleh, N., Jaffar, R., \& Hassan, M. S. (2008). The Influence of Board Independence, Competency and Ownership on Earnings Management in Malaysia. Journal of Economics and Management, 2(2), 281-306.

Johl, S., Jubb, C. A., \& Houghton, K. A. (2007). Earnings management and the audit opinion: evidence from Malaysia. Managerial Auditing Journal, 22(7), 688-715. doi. org/10.1108/02686900710772591 
Waddah Kamal Hassan OMER, Khaled Salmen ALJAAIDI, Mohd Atef Md. YUSOF I

Journal of Asian Finance, Economics and Business Vol 7 No 8 (2020) 289-296

Lin, J. W., \& Hwang, M. I. (2010). Audit Quality, Corporate Governance, and Earnings Management: A Meta-Analysis. International Journal of Auditing, 14(1), 57-77. DOI: 10.1111/j.1099-1123.2009.00403.x

Lorca, C., Sanchez-Ballesta, J. P., \& Garcia-Meca, E. (2011). Board Effectiveness and Cost of Debt. Journal of Business Ethics, 100(4), 613-631. DOI: 10.1007/s10551-010-0699-3

O’Sullivan, M., Percy, M., \& Stewart, J. (2008). Australian evidence on corporate governance attributes and their association with forward-looking information in the annual report. Journal of Management and Governance, 12(1), 5-35. DOI: 10.1007/ s10997-007-9039-0

Porter, B., Simon, J., \& Hatherly, D. (2003). Principles of External Auditing ( $2^{\text {nd }}$ ed.). England: John Wiley \& Sons.

Pucheta-Martinez, M. C., \& de Fuentes, C. (2007). The Impact of Audit Committee Characteristics on the Enhancement of the Quality of Financial Reporting: an empirical study in the Spanish context. An International Review, Corporate Governance Journal, 15(6), 1394-1412. DOI: 10.1111/j.14678683.2007.00653.x

Rahmat. M. M., Iskandar, T. M., \& Saleh, N. M. (2009). Audit committee characteristics in financially distressed and nondistressed companies. Managerial Auditing Journal, 24(7), 624-638. DOI: 10.1108/02686900910975350
Rusmin, R., Tower, G., Brown, A., \& der Zahn, M. V. (2009). Audit Quality, Monitoring Mechanisms and Auditor Reporting Behavior. Working paper.

Sanchez-Ballesta, J. P., \& García-Meca, E. (2005). Audit qualifications and corporate governance in Spanish listed firms. Managerial Auditing Journal, 20(7), 725-738. DOI: 10.1108/02686900510611258

Sultanoglu, B., Mugan, C. S., Sekerdag, U., \& Oran, A. (2018). The auditor's opinion modifications around domestic and global financial crises. Meditari Accountancy Research, 26(4), 622639. DOI: 10.1108/MEDAR-08-2017-0199

Vafeas, N., \& Theodorou, E. (1998). The relationship between board structure and firm performance in the U.K. British Accounting Review, 30(4), 383-407. DOI: U10.1006/bare.1998.0075

Ward, A. J., Brown, J. A., \& Rodriguez, D. (2009). Governance Bundles, Firm Performance, and the Substitutability and Complementarity of Governance Mechanisms. Corporate Governance: An International Review, 17(5), 646-660. DOI: 10.1111/j.1467-8683.2009.00766.x

Watts, R. L., \& Zimmerman, J. L. (1986). Positive Accounting Theory. Englewood Cliffs, NJ: Prentice Hall. 